\title{
KRYZYS FINANSOWY A DETERMINANTY OPROCENTOWANIA OBLIGACJI RZĄDOWYCH W STREFIE EURO
}

\begin{abstract}
W pracy podjęto próbę zbadania zmiany sposobu wyceny przez rynki finansowe obligacji rządowych w państwach strefy euro w okresie kryzysu finansowego. Wartością dodaną artykułu jest sposób traktowania oczekiwanych zmiennych fiskalnych i makroekonomicznych o niskiej częstotliwości. W dodatku do często stosowanej interpolacji statystycznej danych, w artykule skonstruowano i porównano cztery alternatywne schematy oczekiwań rynków finansowych. Takie postępowanie, obok rozwiązania problemu niskiej częstotliwości danych, umożliwia wyciągnięcie pewnych wniosków odnośnie do stopnia dalekowzroczności rynków.

Badanie przeprowadzono na danych kwartalnych, do których sprowadzono dane o wyjściowo różnej częstotliwości, obejmujących lata 1999-2011. Położono nacisk na rolę zmiennych fiskalnych i makroekonomicznych, a także znaczenie stanów nierównowagi w sektorze bankowym. Wyniki potwierdzają wystąpienie silnej zmiany zachowania rynków finansowych. Wskutek kryzysu wzrósł wpływ długu publicznego, popytowych uwarunkowań wzrostu gospodarczego oraz wahań globalnego ryzyka na wysokość premii za ryzyko na oprocentowanie obligacji. Jednocześnie spadło znaczenie płynności rynków obligacji, które przed kryzysem należało do najważniejszych determinant rentowności obligacji. Analiza kontrybucji poszczególnych zmiennych wskazuje, że zarówno przed kryzysem, jak i (jeszcze bardziej) po upadku Lehman Brothers wysokość premii za ryzyko jest silnie powiązana $\mathrm{z}$ sytuacją sektora bankowego, w tym zwłaszcza - z wysokością wskaźnika dźwigni. Sugeruje to, że powiązania między sektorem bankowym i publicznym stanowią ważne źródło obserwowanych fluktuacji premii za ryzyko.
\end{abstract}

Słowa kluczowe: polityka fiskalna, kryzys finansowy, strefa euro

\section{WPROWADZENIE}

W 2008 roku w strefie euro nastąpił zdecydowany wzrost zróżnicowania długoterminowych stóp procentowych. To zjawisko przez wielu ekonomistów zostało zinterpretowano jako poprawa jakości wyceny premii za ryzyko dokonywanej przez rynki finansowe ${ }^{2}$. W istocie $\mathrm{w}$ największym stopniu wzrosły rentowności obligacji greckich, a także irlandzkich i portugalskich. Chociaż każdy z wymienionych krajów znajdował w innej sytuacji makroekonomicznej, to jednak wszystkim rynki finansowe zaczęły przypisywać podwyższone ryzyko kredytowe.

\footnotetext{
${ }^{1}$ Dr Paweł Gajewski, Wydział Ekonomiczno-Socjologiczny, Uniwersytet Łódzki, ul. Rewolucji 1905 r. 41, 90-214 Łódż, e-mail: pawelg@uni.lodz.pl

${ }^{2}$ Por. M.G. Attinasi, C. Checherita, C. Nickel, What Explains the Surge in Euro Area Sovereign Spreads during the Financial Crisis of 2007-09?, „ECB Working Paper” 2009/1131.
} 
Poprawa jakości wyceny ryzyka była argumentem wdrażania w wielu krajach programów oszczędnościowych mających na celu obniżenie relacji długu i deficytu finansów publicznych do produktu krajowego brutto (PKB). Dodatkowe argumenty wspierające działania konsolidacyjne płynęły od ekonomistów wskazujących na możliwość ekspansywnego charakteru konsolidacji fiskalnych dzięki ujawnieniu się w określonych warunkach (m.in. wysoki dług publiczny, oparcie konsolidacji na stronie wydatkowej) efektów niekeynesowskich nawet w krótkim okresie ${ }^{3}$. Na poparcie wywodów teoretycznych przytaczano doświadczenia historyczne zwłaszcza Danii i Irlandii z lat osiemdziesiątych XX wieku, które stały się sztandarowymi przykładami ekspansywnych konsolidacji ${ }^{4}$. Krótkookresowe efekty konsolidacji fiskalnych okazały się jednak gorsze od oczekiwanych. Stopa wzrostu gospodarczego w krajach nimi objętych w 2011 roku był niska, a często ujemna, prognozy zaś na kolejne lata rzadko zwiastują odwrócenie negatywnych trendów.

W związku z tym coraz częściej zaczęły się pojawiać głosy kwestionujące realne możliwości wystąpienia efektów niekeynesowskich w takiej skali, aby mogły one przeważyć nad klasycznymi efektami keynesowskimi ${ }^{5}$. Między innymi Blanchard ${ }^{6}$ i Portes $^{7}$ twierdzą, że konsolidacje fiskalne nie tylko obniżają wzrost PKB, ale także są przeciwskuteczne. Dzieje się tak dlatego, że rynki finansowe zdają się w większym stopniu wyceniać obligacje na podstawie perspektywy wzrostu gospodarczego niż wyników fiskalnych. Wdrażając programy oszczędnościowe i tłumiąc wzrost gospodarczy, rządy przyczyniają się zatem do wzrostu rentowności obligacji i wzrostu relacji długu do PKB za sprawą zarówno wzrostu licznika (wzrost płatności odsetkowych), jak i spadku mianownika.

Prezes MFW Oliver Blanchard, komentując w kwietniu 2012 roku ostrzeżenie wystosowane pod adresem rządu hiszpańskiego o potencjalnie negatywnych konsekwencjach zacieśnienia fiskalnego, stwierdził, że rynki finansowe cierpią na schizofrenię (wypowiedział wówczas cytowane obecnie często zdanie „Damned if you do, damned if you don' 't').

Niewątpliwie w 2008 roku dokonała się zmiana strukturalna sposobu wyceny obligacji rządowych w strefie euro, przy czym pewna frustracja wśród ekonomistów i polityków wskazuje, że nowe mechanizmy tej wyceny nie są do końca znane. Aktualne jest zwłaszcza pytanie, czy wzrost rentowności obligacji jest rzeczywiście związany z podwyższonym ryzykiem kredytowym? Czy ważniejszą rolę odgrywają inne czynniki, takie jak wahania globalnej awersji do ryzyka, płynność obligacji lub nierównowagi występujące $\mathrm{w}$ sektorze prywatnym, które potencjalnie mogą być w przyszłości zaabsorbowane przez sektor publiczny, zwykle poprzez wzrost zadłużenia publicznego?

Krótkie szeregi czasowe wciąż stanowią barierę dla badań empirycznych, ale z upływem czasu możliwości analizy determinantów oprocentowania obligacji są większe. Niniejsze opracowanie stanowi kolejną próbę oszacowania determinantów oprocentowania obligacji, a także zbadania skali wspomnianej zmiany strukturalnej

\footnotetext{
${ }^{3}$ Por. np. P. Borys, P. Ciżkowicz, A. Rzońca, Panel data evidence on non-Keynesian effects of fiscal policy in the EU New Member States, „MPRA Paper” 2011/32696, University Library of Munich, Germany.

${ }^{4}$ Por. MFW, Navigating the Fiscal Challenges Ahead, "Fiscal Monitor", Maj 2010.

${ }^{5}$ Por. G. Corsetti, Has Austerity Gone Too Far?, VOXEU.org, 2.04.2012 r.

${ }^{6}$ O. Blanchard Driving the Global Economy with the brakes on, blogpost, styczen $2012 \mathrm{r}$.

${ }^{7}$ J. Portes Is austerity self-defeating? Of course it is, VOXEU.org, 10.04.2012 r.
} 
sposobu wyceny ich rentowności w okresie nasilania się i utrzymywania zjawisk kryzysowych. Weryfikacji poddawana jest między innymi hipoteza, że rynki finansowe przed kryzysem finansowym brały pod uwagę głównie płynność rynków obligacji oraz zmienne fiskalne, natomiast od 2008 roku w większym stopniu wyceniają obligacje rządowe na podstawie wskaźników makroekonomicznych. Przeanalizowano ponadto rolę zmiennych opisujących ryzyko płynące $\mathrm{z}$ sektora bankowego w tłumaczeniu zmienności rentowności obligacji. Dodatkowym celem pracy jest przybliżenie sposobu wyceny obligacji przez rynki finansowe na podstawie prognozowanych danych makroekonomicznych i fiskalnych.

W pierwszej części opracowania zawarto przegląd literatury, zwłaszcza dotychczasowych badań empirycznych dotyczących determinantów oprocentowania obligacji rządowych. W drugiej części zaś przedstawiono prosty model empiryczny wykorzystany do analizy. Opis zmiennych oraz sposoby interpolacji danych prognozowanych zawarto $\mathrm{w}$ części trzeciej. W czwartej części przedstawiono wyniki badań. Opracowanie kończy podsumowanie, w którym zawarto też najważniejsze wnioski.

\section{PRZEGLĄD LITERATURY}

Proces tworzenia się strefy euro w drugiej połowie lat dziewięćdziesiątych XX wieku zaowocował wyrównaniem i jednocześnie dynamicznym spadkiem oprocentowania obligacji $\mathrm{w}$ krajach tworzących ten organizm. Zjawisko to było konsekwencją między innymi eliminacji ryzyka kursowego, kredytu zaufania udzielonego przez rynki finansowe, a gwarantowanego przez najbardziej wiarygodne kraje uczestniczące w tym projekcie, a także poprawy wskaźników fiskalnych oraz stłumienia inflacji, wymuszonymi przez zapisy powstającego Paktu Stabilności i Wzrostu.

W tych warunkach zmniejszyło się zainteresowanie mechanizmami wyceny obligacji rządowych na rynkach finansowych. Wprawdzie prowadzono badania determinantów rentowności obligacji ${ }^{8}$, ale dopiero gwałtowny wzrost ich zróżnicowania, jaki nastąpił pod wpływem kryzysu finansowego w 2008 roku, zaowocował pojawieniem się wielu nowych artykułów podejmujących próbę wyjaśnienia tego zjawiska.

W literaturze ekonomicznej można zidentyfikować dwa główne podejścia do analizy determinantów oprocentowania obligacji rządowych. Pierwsza grupa badań koncentruje się na krótkookresowych fluktuacjach stóp procentowych ${ }^{9} \mathrm{w}$ zależności od zmiennych finansowych, wskaźników awersji do ryzyka, płynności obligacji etc. Badania te oparte

\footnotetext{
${ }^{8}$ Między innymi L. Codogno, C. Favero, A. Missale, Yield spreads on EMU government bonds, „Economic Policy” 2003/18, s. 503-532; A. Geyer, S. Kossmeier, S. Pichler, Measuring systematic risk in EMU government yield spreads „Review of Finance” 2004/8(2), s.171-197.; M. Pagano, von Thadden E., The European Bond Markets Under EMU, „CEPR Discussion Paper” 2004/4779; C. Favero, M. Pagano, E. von Thadden, Valuation, Liquidity and Risk in Government Bond Markets, ,IGIER Working Paper” 2005/281; M. Gómez-Puig, Monetary integration and the cost of borrowing, ,Journal of International Money and Finance” 27/3 (2008), s. 455479 .

9 W obu grupach modelowane są relatywne stopy procentowe, czyli różnice między oprocentowaniem obligacji danego kraju a oprocentowaniem obligacji bezpiecznych - w wypadku strefy euro na ogół niemieckich bundów.
} 
są na danych o wysokiej częstotliwości (dzienne, tygodniowe), umożliwiaja wyodrębnienie nieobserwowalnych czynników wspólnych i krajowych i są przydatne między innymi w szacowaniu skali efektów zarażania. Niemniej jednak w ramach tego podejścia nie jest możliwe określenie skali wpływu czynników makroekonomicznych i fiskalnych na poziom premii za ryzyko kredytowe i (tym samym) oprocentowanie obligacji.

W drugiej grupie badań, do której należy także niniejsze opracowanie, nacisk położony jest na rolę zmiennych makroekonomicznych i fiskalnych. Z teoretycznego punktu widzenia na stopę oprocentowania obligacji rządowych kraju należącego do strefy euro składają się przede wszystkim: zwrot z inwestycji pewnej, premia za ryzyko wspólne strefy euro (wynikające z oczekiwań zmian kursu euro i prowadzonej polityki pieniężnej), premia za ryzyko kredytowe, premia za ryzyko płynności oraz natężenie globalnej awersji do ryzyka. W wypadku modelowania odchyleń od rentowności obligacji niemieckich pierwsze dwa komponenty są wyeliminowane, dlatego też analizy koncentrują się na pozostałych.

W świetle wyników większości publikowanych badań dużą rolę w objaśnianiu zmian relatywnych stóp procentowych odgrywają czynniki globalne, powiązane $\mathrm{z}$ wahaniami awersji do ryzyka. Do takich wniosków doszli zarówno Codogno i wsp. ${ }^{10}$, badając okres przed utworzeniem strefy euro oraz pierwsze lata funkcjonowania tego organizmu, jak i autorzy późniejszych analiz, w tym zwłaszcza prowadzonych na danych po 2008 roku $^{11}$. We wszystkich (znanych autorowi) badaniach wzrost globalnej awersji do ryzyka okazywał się istotnym czynnikiem podnoszącym zróżnicowanie rentowności obligacji w strefie euro, mimo kontroli zmiennych opisujących warunki specyficzne poszczególnych gospodarek. Tłumaczyć to należy restrukturyzacją portfeli w kierunku zwiększenia udziału aktywów bezpiecznych, jaka dokonuje się w odpowiedzi na podwyższoną niepewność. Wahania globalnej awersji do ryzyka mierzone są na ogół różnicą pomiędzy oprocentowaniem obligacji rządowych Stanów Zjednoczonych i obarczonych średnim bądź wysokim ryzykiem obligacji korporacyjnych ${ }^{12}$. Alternatywnie wykorzystywaną zmienną jest wartość indeksu zmienności VIX ${ }^{13}$, przy czym jej zastosowanie nie zmienia najważniejszych wniosków o silnej statystycznej istotności tego zjawiska ${ }^{14}$. Jeszcze inne zmienne wykorzystują (z podobnym skutkiem) Cagggiano, Greco ${ }^{15}$.

Statystycznie istotne okazują się też często zmienne aproksymujące płynność rynków obligacji, na którą składają się głębokość rynku, czyli liczba zawieranych

\footnotetext{
${ }^{10}$ L. Codogno, C. Favero, A. Missale, op. cit.

${ }^{11}$ Por. np. M.G. Attinasi, C. Checherita, C. Nickel, op. cit.; S. Gerlach, A. Schulz, G. Wolff, Banking and Sovereign Risk in the Euro Area, CEPR Discussion Paper No. DP7833, 2010.; G. Caggiano, L. Greco, Sovereign Risk in the Euro Area: Is it Mostly Fiscal or Financial, mimeo, 2011.

${ }^{12}$ Na przykład L. Codogno, C. Favero, A. Missale, op. cit ; S. Gerlach, A. Schulz, G. Wolff op.cit.; L. Schuknecht, J. von Hagen, G. Wolswijk, Government Bond Risk Premiums in the EU Revisited. The Impact of the Financial Crisis, „ECB Working Paper” 2010/1152.

13 Chicago Board Options Exchange Market Volatility Index - wskaźnik implikowanej zmienności indeksu opcji S\&P 500.

${ }_{14}$ Por. np. M. Arghyrou, A. Kontonikas, The EMU sovereign-debt crisis: Fundamentals, expectations and contagion, „Cardiff Economics Working Papers” E2010/9, Cardiff University.

${ }^{15}$ G. Caggiano, L. Greco, op.cit.
} 
transakcji kupna i sprzedaży, oraz szerokość rynku, która jest tym większa, im bardziej cena rynkowa obligacji jest odporna na duże transakcje ${ }^{16}$. Mała płynność rynku wiąże się z ryzykiem konieczności zaakceptowania dużej różnicy między ceną kupna i sprzedaży obligacji. Patrząc przez pryzmat obu charakterystyk, najbardziej płynnym rynkiem obligacji w strefie euro jest rynek bundów, co oznacza, że premia za płynność na pozostałych rynkach powinna być większa. Zmiennymi najczęściej wykorzystywanymi do aproksymowania płynności rynków obligacji są: różnice pomiędzy ceną kupna i sprzedaży (bid-ask spreads), wartość wyemitowanych obligacji pozostających w obrocie lub wartości wolumenu obligacji sprzedawanych w jednostce czasu. Dowody empiryczne na istotną rolę tych zmiennych w kształtowaniu relatywnych stóp procentowych są mieszane. Na ogół jednak autorzy potwierdzają ich statystyczną istotność zarówno przed nasileniem się zjawisk kryzysowych w strefie euro, jak i w czasie kryzysu ${ }^{17}$. Beber i wsp. ${ }^{18}$ dowodzą, że w okresie napięć na rynkach płynność (w większym stopniu niż niskie ryzyko kredytowe) staje się kluczową zmienną rynków obligacji, pożądaną przez rynki finansowe. Do odmiennych wniosków dochodzą Schuknecht i wsp. ${ }^{19}$. W ich analizie wskaźniki płynności okazują się nieistotne niezależnie od badanej podpróby. Ogólnie można podsumować, że w większości badań płynność w okresie kryzysu okazuje się słabszym czynnikiem determinującym zróżnicowanie rentowności obligacji państw strefy euro w porównaniu z wahaniami globalnego ryzyka.

Empiryczna weryfikacja czynników determinujących premię za ryzyko kredytowe, czyli rekompensatę za tolerowanie niezerowego prawdopodobieństwa częściowego lub całkowitego niewywiązania się rządu z umowy zawartej poprzez sprzedaż obligacji, stwarza większe problemy. $Z$ jednej strony na prawdopodobieństwo bankructwa kraju wpływa nie tylko wiele czynników powiązanych z tempem akumulacji zadłużenia publicznego, ale także osiągane wyniki makroekonomiczne, sytuacja w sektorze finansowym, czy w otoczeniu zewnętrznym. Z drugiej strony należy brać pod uwagę problem rodzaju danych statystycznych wykorzystywanych do analiz.

Przede wszystkim należy dokonać wyboru pomiędzy danymi historycznymi a danymi prognozowanymi. Dane historyczne są łatwo dostępne w bazach statystycznych, dlatego też bardzo popularne są badania prowadzone na ich podstawie, zwłaszcza we wcześniejszym okresie ${ }^{20}$, ale także później ${ }^{21}$. Wydaje się jednak, że dane

\footnotetext{
${ }^{16}$ Por. S. Barrios, P. Iversen, M. Lewandowska, R. Setzer, Determinants of Intra-Euro Area Government Bond Spreads during the Financial Crisis, „EC Economic Papers” 2009/388.

17 Por. np. M.G. Attinasi, C. Checherita, C. Nickel, op. cit;; S. Barrios, P. Iversen, M. Lewandowska, R. Setzer, op. cit.; S. Gerlach, A. Schulz, G. Wolff op.cit.

${ }^{18}$ A. Beber, M.W. Brandt, K.A. Kavajecz, Flight-to-Quality or Flight-to-Liquidity? Evidence from the Euro-Area Bond Market, ,Review of Financial Studies, Oxford University Press for Society for Financial Studies" 22/3 (2009), s. 925-957.

${ }^{19}$ L. Schuknecht, J. von Hagen, G. Wolswijk, op. cit.

${ }^{20}$ Na przykład: K. Bernoth, J. von Hagen, L. Schuknecht, Sovereign risk premia in the European government bond market, "ZEI Working Papers" B 26-2003, ZEI - Center for European Integration Studies, University of Bonn, 2003.; L. Codogno, C. Favero, A. Missale, op. cit.

${ }^{21}$ Na przykład C. Aßmann, J. Boysen-Hogrefe, Determinants of government bond spreads in the Euro Area - in good Times as in bad, „Kiel Working Paper” 2009/1548; P. De Grauwe, Y. Ji, Mispricing of Sovereign Risk and Multiple Equilibria in the Eurozone, „CEPS Working Document No 361" (2012).
} 
prognozowane zdecydowanie lepiej oddają parametry, na których podstawie rynki finansowe wyceniają swoją premię za ryzyko w danym okresie. W ostatnich latach zdecydowanie częściej analizy oparte są właśnie na takich danych, mimo niższej częstotliwości ich publikacji.

Dostępne w literaturze ekonomicznej opracowania różnią się pod względem traktowania zmiennych oczekiwanych, które na ogół są dostępne w odstępach nie mniejszych niż półroczne (prognozy Komisji Europejskiej, OECD). Wprawdzie możliwe jest uzyskanie z niektórych źródeł prognoz o wyższej częstotliwości (np. miesięcznej z Consensus Economic Forecasts), ale nie są nimi objęte wszystkie kraje strefy euro oraz wszystkie niezbędne zmienne.

Problem niskiej częstotliwości zmiennych oczekiwanych jest najczęściej rozwiązywany poprzez interpolację, która umożliwia uzyskanie zbioru danych o częstotliwości kwartalnej lub miesięcznej. Przykłady analiz opartych na danych interpolowanych do częstotliwości miesięcznych można znaleźć między innymi w pracach: Attinasi i wsp. ${ }^{22}$, Sgherri i Zolli ${ }^{23}$, Barbosa i Costa ${ }^{24}$. Interpolowane dane kwartalne $\mathrm{z}$ kolei wykorzystywano w pracach na przykład Haugh ${ }^{25}$, Barrios i wsp. ${ }^{26}$, Caggiano, Greco $^{27}$. Warto podkreślić, że mechaniczna interpolacja danych umożliwia stworzenie danych o dowolnie wysokiej częstotliwości, przy czym prowadzi do pogłębiania błędu pomiaru (interpolation error), który jest rosnącą funkcją odległości między punktami danych, a także autokorelacji, która musi być następnie uwzględniona przy estymacji.

W celu uchwycenia czynników determinujących wysokość premii za ryzyko należy uwzględnić zmienne opisujące sytuację przynajmniej w trzech obszarach: finansów publicznych, sfery realnej oraz sektora finansowego.

Związek pomiędzy długiem publicznym a oprocentowaniem obligacji był dość dobrze udokumentowany jeszcze przed powstaniem strefy euro ${ }^{28}$. Wyniki nowszych analiz pokazują, że oszacowania parametrów przy zmiennych fiskalnych (zwłaszcza przy długu publicznym) po zmianie strukturalnej z 2008 roku są kilkakrotnie wyższe niż przed kryzysem ${ }^{29}$. Na ogół lepsze wyniki są też uzyskiwane w badaniach dopuszczających nieliniowy wpływ długu na rentowności obligacji ${ }^{30}$. W większości

${ }^{22}$ M.G. Attinasi, C. Checherita, C. Nickel, op. cit.

${ }^{23}$ S. Sgherri, E. Zoli, Euro Area Sovereign Risk During the Crisis, „IMF Working Paper” 9/222 (2009).

${ }^{24}$ L. Barbosa, S. Costa, Determinants of sovereign bond yield spreads in the euro area in the context of the economic and financial crisis, "Economic Bulletin and Financial Stability Report Articles", Banco de Portugal, Economics and Research Department 2010.

${ }^{25}$ D. Haugh, P. Ollivaud, D. Turner, What Drives Sovereign Risk Premiums?: An Analysis of Recent Evidence from the Euro Area, „OECD Economics Department Working Papers” $2009 / 718$

${ }^{26}$ S. Barrios, P. Iversen, M. Lewandowska, R. Setzer, op. cit.

${ }^{27}$ G. Caggiano, L. Greco, op.cit.

${ }^{28}$ A. Alesina, M. De Broeck, A. Prati, G. Tabellini, Default Risk on Government Debt in OECD Countries, „Economic Policy” 1992/15, s. 427-451; M. Goldstein, G. Woglom, Market Based Fiscal Discipline in Monetary Unions: Evidence from the US Municipal Bond Market, w: (red.) M. Canzoneri, V. Grilli, P. Masson, "Establishing a Central Bank", Cambridge University Press, 1992, cyt. za: M.G. Attinasi, C. Checherita, C. Nickel, op. cit.

${ }^{29}$ Por. np. L. Schuknecht, J. von Hagen, G. Wolswijk, op. cit.

${ }^{30}$ S. Barrios, P. Iversen, M. Lewandowska, R. Setzer, op. cit.; G. Caggiano, L. Greco, op.cit. 
wypadków udaje się także empirycznie potwierdzić istotny wpływ salda budżetowego, którego poprawa obniża rentowność obligacji rządowych w strefie euro.

$\mathrm{Z}$ punktu widzenia inwestorów istotnym czynnikiem determinującym premię za ryzyko kredytowe może być także sytuacja w sferze realnej. Codogno i wsp. ${ }^{31}$ zauważają, że przyszła zdolność do obsługi długu zależy od aktualnego i przyszłego poziomu inwestycji i dochodu. Wysoka dynamika PKB $\mathrm{z}$ jednej strony pomaga utrzymać/odzyskać równowagę finansów publicznych, a z drugiej jest dla rynków finansowych sygnałem konkurencyjności gospodarki. Caggiano, Greco ${ }^{32}$ wskazują, że wpływ krótkookresowych oczekiwań wzrostu PKB na rentowność obligacji w okresie kryzysu jest nawet kilkunastokrotnie wyższy niż przed kryzysem.

W części analiz do zbioru zmiennych objaśniających włączane są inne zmienne opisujące sytuację w sferze realnej, na przykład saldo obrotów bieżących (w relacji do PKB), które można traktować jako wskaźnik nierównowagi zewnętrznej. Barrios i wsp. ${ }^{33}$ dowodzą, że poprawa tego salda istotnie obniża wysokość premii za ryzyko i rentowność obligacji w strefie euro.

Oprócz sytuacji w finansach publicznych oraz w sferze realnej rynki finansowe w dużym (i rosnącym) stopniu są zainteresowane powiązaniami między sytuacją sektora bankowego i ryzykiem kredytowym kraju. Warto podkreślić, że powiązania te mogą być dwukierunkowe, w zależności od sytuacji makroekonomicznej. W okresie dobrej koniunktury duży sektor bankowy wspiera wzrost gospodarczy i jest źródłem dochodów budżetowych $^{34}$. Z kolei pogorszeniu sytuacji gospodarczej może towarzyszyć oczekiwane pogorszenie jakości aktywów. Dlatego też w okresie obecnego kryzysu finansowego, wobec wysokich wskaźników dźwigni podtrzymywanych przez banki działające w strefie euro, wzrosło zagrożenie koniecznością wykorzystania środków publicznych do ratowania banków prywatnych w okresie kryzysu finansowego. W praktyce pomoc ze środków publicznych jest alternatywą dla często silnego procesu delewarowania, kredytowego crunchu i gwałtownego obniżenia popytu inwestycyjnego, które przekłada się na pogorszenie krótkookresowych perspektyw wzrostu gospodarczego. Ryzyko akumulacji długu publicznego poprzez pomoc sektorowi bankowemu materializowało się w strefie euro już kilkakrotnie po upadku Lehman Brothers we wrześniu 2008 roku i z pewnością pozostaje jednym z komponentów ryzyka kredytowego przypisywanego poszczególnym gospodarkom. Empirycznych dowodów potwierdzających wpływ finansowego wspierania sektora bankowego na wzrost oprocentowania obligacji rządowych dostarczają między innymi Acharya i wsp. $^{35}$. Także Gerlach i wsp. ${ }^{36}$ dowodzą, że wielkość sektora bankowego staje się czynnikiem podwyższającym premię za ryzyko, zwłaszcza w okresach rosnącej globalnej awersji do ryzyka.

\footnotetext{
${ }^{31}$ L. Codogno, C. Favero, A. Missale, op. cit.

${ }^{32}$ G. Caggiano, L. Greco, op.cit.

${ }^{33}$ S. Barrios, P. Iversen, M. Lewandowska, R. Setzer, op. cit.

${ }^{34}$ Por. S. Gerlach, A. Schulz, G. Wolff op.cit.

${ }^{35}$ V. Acharya L. Drechsler P. Schnabl, A Pyrrhic Victory? - Bank Bailouts and Sovereign Credit Risk, ,NBER Working Papers” 17136 (2011).

${ }^{36}$ S. Gerlach, A. Schulz, G. Wolff op.cit.
} 
Część autorów wykorzystuje oceny ratingowe w roli zmiennych aproksymujących ryzyko kredytowe ${ }^{37}$. Należy jednak mieć na uwadze, że oceny te charakteryzują się małą zmiennością $\mathrm{i}$ same $\mathrm{w}$ sobie są wynikiem kształtowania się zmiennych makroekonomicznych, fiskalnych i finansowych, o których była mowa.

\section{MODEL EMPIRYCZNY}

Niniejsze opracowanie ma na celu identyfikację czynników determinujących premie za: ryzyko kredytowe, ryzyko płynności oraz ryzyko globalne, które są komponentami stóp oprocentowania obligacji rządowych w strefie euro. W tym celu wykorzystano standardowy model, w którym zmienną objaśnianą jest odchylenie oprocentowania 10letnich obligacji w kraju $i$ od oprocentowania analogicznych obligacji niemieckich:

$$
\begin{aligned}
& s_{i t}-s_{g, t}=\alpha+\boldsymbol{\beta}_{1} \cdot\left(\mathbf{X}_{i, t}-\mathbf{X}_{g, t}\right)+\beta_{2} \\
& +\beta_{3} \cdot \ln \left(l i q_{i, t}-l i q_{g, t}\right)+\beta_{4} \cdot\left(\mathrm{B}_{i, t}-\mathrm{I}\right.
\end{aligned}
$$

Zbiór zmiennych objaśniających zawiera zmienne opisujące sytuację makroekonomiczną i fiskalną każdego kraju (wektor prognozowanych zmiennych $\mathbf{X}_{i, t}$ ), sytuację sektora bankowego $\left(\mathrm{B}_{i, t}\right)$, a także zmienną aproksymującą płynność krajowego rynku obligacji $\left(l i q_{i, t}\right)$ oraz wskaźnik globalnego ryzyka $\left(\right.$ risk $\left._{t}\right)$. Wszystkie zmienne indywidualne dla poszczególnych gospodarek są de facto odchyleniami od wartości zarejestrowanych w Niemczech w tym samym kwartale. Bardziej szczegółowy opis wykorzystanych danych oraz przeprowadzonych transformacji znajduje się w następnej części opracowania.

Liczba obserwacji dla każdego kraju (38 kwartałów przed kryzysem i 14 kwartałów od rozpoczęcia kryzysu ${ }^{38}$ ) jest relatywnie mała, zwłaszcza biorąc pod uwagę fakt, że równocześnie testowanych jest 10-12 zmiennych objaśniających. Tym samym estymacja parametrów równania (1) dla każdego kraju oddzielnie byłaby problematyczna i lepszym rozwiązaniem jest wykorzystanie metod panelowych.

Procedura estymacji parametrów równania (1) jest bardzo podobna do procedury zastosowanej przez Barrios i wsp. ${ }^{39}$ i bazuje na metodzie zaproponowanej w pracy Beck, Katz ${ }^{40}$, tzw. panel corrected standard errors (PCSE). Jak wskazują Barrios i wsp. $^{41}$, innym możliwym podejściem wobec występowania autokorelacji byłaby estymacja dynamicznego panelu metodą Arellano-Bonda ${ }^{42}$. Metoda ta jest jednak

37 S. Manganelli, G. Wolswijk, What Drives Spreads in the Euro Area Government Bond Market?, „Economic Policy” 2009/58, s. 191-240; R. De Santis, The Euro area sovereign debt crisis: safe haven, credit rating agencies and the spread of the fever from Greece, Ireland and Portugal, „Working Paper Series” 1419, European Central Bank (2012).

${ }^{38}$ Umownie przyjęto, że podział między tymi dwoma okresami nastąpił w III kwartale 2008 roku, w którym upadł bank Lehman Brothers.

${ }^{39}$ S. Barrios, P. Iversen, M. Lewandowska, R. Setzer, op. cit.

${ }^{40}$ N. Beck, J. N. Katz, What To Do (and Not To Do) with Time-Series Cross-Section Data, „American Political Science Review” 1995/89, s. 634-47.

${ }_{41}$ S. Barrios, P. Iversen, M. Lewandowska, R. Setzer, op. cit.

${ }^{42}$ M. Arellano, S. Bond, Some Tests of Specification for Panel Data: Monte Carlo Evidence and an Application to Employment Equations, ,Review of Economic Studies”, 1991/58(2), s. 277-97. 
skonstruowana dla paneli o dużej liczbie obiektów (N) i relatywnie krótkich szeregach czasowych (T).

Metoda PCSE jest metodą alternatywną w stosunku do EMNK $(F G L S)$, która jednak wymaga spełnienia warunku $\mathrm{N}>\mathrm{T}$. Estymator PCSE jest przy tym odporny na występowanie heteroskedastyczności oraz korelacji pomiędzy składnikami losowymi dla poszczególnych krajów. Dodatkowo, dzięki zastosowaniu procedury PraisaWinstena, możliwa jest kontrola autokorelacji składników losowych. Założono, że składniki losowe podlegają procesowi AR(1), a współczynniki autokorelacji są indywidualne dla każdego kraju. Efekty indywidualne dla krajów są kontrolowane przez efekty ustalone (fixed effects) ${ }^{43}$.

\section{DANE STATYSTYCZNE}

Zmienną objaśnianą jest różnica między oprocentowaniem 10-letnich obligacji rządowych kraju $i$ a oprocentowaniem 10-letnich obligacji niemieckich. Zbiór zmiennych objaśniających zawiera odchylenia następujących zmiennych od ich wartości zarejestrowanych w Niemczech:

Płynność krajowych rynków obligacji aproksymowana jest wartością długu na rynku wtórnym (dane pochodzą z Bank for International Settlements - BIS). Do opisu sytuacji makroekonomicznej kraju wykorzystywane są następujące zmienne: stopa wzrostu PKB, stopa oszczędności, stopa bezrobocia, wskaźnik jednostkowych kosztów pracy i saldo obrotów bieżących (jako procent PKB). Dwie wykorzystywane zmienne fiskalne to dług sektora rządowego i samorządowego oraz deficyt tego sektora. Wszystkie zmienne makroekonomiczne i fiskalne są prognozowane i pochodzą z biannualnych publikacji OECD Economic Outlook. Ryzyko płynące z sektora bankowego jest aproksymowane za pomocą relacji całkowitych aktywów do wartości kapitału i rezerw oraz (alternatywnie) stosunku udzielonych pożyczek do zgromadzonych depozytów. Dodatkowo testowano: stosunek aktywów do PKB oraz pożyczek do depozytów prywatnych, ale empiryczne rezultaty okazały się gorsze niż w wypadku pierwszych dwóch zmiennych. Źródłem danych opisujących ryzyko z sektora bankowego jest ECB Statistical Data Warehouse.

Zjawiskiem wspólnym dla wszystkich krajów jest globalny poziom awersji do ryzyka, mierzony różnicą pomiędzy oprocentowaniem 10-letnich obligacji amerykańskich a przeciętnym oprocentowaniem obligacji korporacyjnych średniego ryzyka (o ratingu Baa). Źródłem tych danych jest Bureau for Economic Analysis (BEA).

Zmienne te tworzą zbiór danych kwartalnych w okresie 1 kwartału 1999 roku - 4 kwartału 2011 roku. W modelu dopuszczono możliwość nieliniowego wpływu relacji długu publicznego do PKB, a także zmiennych z sektora bankowego na oprocentowanie obligacji.

W związku z niską częstotliwością danych prognozowanych istnieje konieczność ich interpolacji do wyższej częstotliwości. Zamiast wykorzystania zwyczajowej procedury interpolacji liniowej albo wielomianowej wyższego stopnia, w niniejszym opracowaniu interpolacja jest przeprowadzona na podstawie założeń dotyczących oczekiwań rynków finansowych (procedurę interpolacji wykorzystano do

${ }^{43}$ Czyli w praktyce stałą w równaniu (1) dla $i$-tego kraju niebazowego można zapisać jako $\alpha+\alpha_{i}$. 
przetestowania kilku rodzajów możliwych schematów oczekiwań). Publikacje OECD Economic Outlook są upowszechniane w czerwcu oraz grudniu każdego roku. Przyjęto, że prognozy zawarte $\mathrm{w}$ tych publikacjach są znane (antycypowane) odpowiednio w drugim i czwartym kwartale. Nasuwają się następujące pytania: w jaki sposób zmieniają się oczekiwania pomiędzy publikacjami kolejnych prognoz? Czy rynki finansowe, wyceniając ryzyko kredytowe, analizują prognozy na rok obecny, kolejny, czy też stopniowo, z upływem kwartałów, przenoszą uwagę na coraz odleglejszy horyzont?

$\mathrm{Na}$ potrzeby niniejszego opracowania przyjęto cztery alternatywne schematy interpolacji zmiennych $\mathbf{X}_{t}{ }^{44}$ :

1) wygładzone prognozy na rok bieżący (w II i IV kwartale z publikacji OECD Outlook, w I i III kwartale - interpolowane liniowo);

2) wygładzone prognozy na rok $\mathrm{t}+1$ (analogicznie jak w schemacie 1 );

3) ważone prognozy na lata $\mathrm{t}-1$, t i t +1 , tak że macierz oczekiwanych zmiennych można zapisać jako:

$$
\begin{aligned}
& {\left[\begin{array}{c}
x_{t, 1} \\
x_{t, 2} \\
x_{t, 3} \\
x_{t, 4}
\end{array}\right]=} \\
& {\left[\begin{array}{c}
x_{t-1} \cdot 0,25+x_{t} \cdot 0,75 \\
x_{t} \\
x_{t} \cdot 0,75+x_{t+1} \cdot 0,25 \\
x_{t} \cdot 0,5+x_{t+1} \cdot 0,5
\end{array}\right] \begin{array}{l}
\text { zrodto: OECD Economic Outlook, Decembert }-1 \\
\text { Zrodto: OECD Economic Outlook, OECD Economic Outlook, } \\
\text { zrone }
\end{array}}
\end{aligned}
$$

gdzie $\boldsymbol{x}_{\boldsymbol{t}, \boldsymbol{n}}$ jest transponowanym wektorem oczekiwanych zmiennych makroekonomicznych i fiskalnych w kwartale n, roku t;

4) prognozy ważone (jak w schemacie 3) i jednocześnie wygładzone (jak w schematach 1 i 2 ).

\section{WYNIKI}

W celu oszczędności miejsca przedstawiono tylko wyniki oparte na dwóch schematach interpolacji, które okazały się generować najlepsze rezultaty - pierwszym i czwartym.

Estymując równanie (1) na pełnej próbie otrzymuje się wyższy współczynnik determinacji przy założeniu pierwszego (prostego) schematu oczekiwań. Relatywne oprocentowanie obligacji rządowych zależy w tym wariancie od wskaźnika ryzyka globalnego, oczekiwanej relacji długu publicznego do PKB, a także od oczekiwanej stopy bezrobocia na koniec roku.

\footnotetext{
${ }^{44}$ Dla każdego kraju. W celu zwiększenia przejrzystości zrezygnowano z subskryptu $i$ w prezentacji schematu interpolacji (3).
} 
Tabela 1. Wyniki estymacji parametrów równania (1) w pełnej próbie

\begin{tabular}{|c|c|c|c|c|}
\hline Zmienna & Pełna (1) & Pełna (2) & Pełna (3) & Pełna (4) \\
\hline Ryzyko globalne & $.0710919^{* * *}$ & $.06603652 * * *$ & $.07082815^{* * *}$ & $.06443254 * * *$ \\
\hline aktywa/kap. & $-.10861712 * *$ & $-.08565886^{*}$ & & \\
\hline$(\text { aktywa/kap.) })^{2}$ & $.00243536^{* * *}$ & .00159127 & & \\
\hline poż./dep. & & & .98907423 & -.39833962 \\
\hline$(\text { poż./dep. })^{2}$ & & & .23272395 & 1.7926994 \\
\hline Płynność & .33899041 & $.43574738^{*}$ & .28572623 & $.34877822^{*}$ \\
\hline $\mathrm{E}(\mathrm{BOB})$ & .00871096 & .01116267 & .01890525 & .01483826 \\
\hline $\mathrm{E}(\mathrm{y})$ & -2.0164512 & -2.3339217 & -2.0407512 & -1.9949028 \\
\hline $\mathrm{E}$ (dług) & $.03048673^{* * *}$ & $.01029804^{* *}$ & $.03382086^{* * *}$ & .00746913 \\
\hline $\mathrm{E}(\mathrm{dlug})^{2}$ & -.00015921 & -.00009319 & -.00012697 & -.00006865 \\
\hline E(saldo gg) & -.02315997 & -.00054548 & -.02275459 & .00063355 \\
\hline $\mathrm{E}(\mathrm{ulc})$ & .5254537 & .12258211 & 64618081 & .30889628 \\
\hline E(stopa oszcz.) & .01088659 & .00272169 & .01817845 & .00628352 \\
\hline E(stopa bezr.) & $.07359028^{* *}$ & .02434307 & $.07217705^{* *}$ & .01924692 \\
\hline _cons & -.52175677 & -1.3545113 & -1.2828062 & $-1.7996905^{*}$ \\
\hline $\mathrm{N}$ & 397 & 399 & 397 & 399 \\
\hline $\mathrm{R}^{2}$ & .25262632 & .18614322 & .25533588 & .11945233 \\
\hline
\end{tabular}

$*, * *, * * *$ oznaczają istotność na poziomie (odpowiednio) 10\%, 5\% i 1\%.

Źródło: opracowanie własne.

Wyniki zestawione w tabeli 1 dostarczają niejednoznacznych wniosków odnośnie do roli zmiennych z sektora bankowego. Relacja udzielonych pożyczek do depozytów okazała się nieistotna, natomiast relacja całkowitych aktywów do kapitału i rezerw jest istotna, a wpływ tej zmiennej na zmienną objaśnianą jest nieliniowy. Ryzyko kraju (a wraz z nim oprocentowanie obligacji) rośnie dopiero po osiągnięciu przez banki relatywnie wysokich wskaźników dźwigni. Pozostałe uwzględnione zmienne okazały się statystycznie nieistotne. Warto zauważyć, że współczynnik determinacji modelu oszacowanego na pełnej próbie jest zdecydowanie niższy niż współczynniki dla modeli estymowanych na dwóch wyróżnionych podpróbach, co można zinterpretować jako potwierdzenie zmiany strukturalnej, jaka dokonała się na rynkach finansowych po upadku Lehman Brothers. 
Tabela 2. Wyniki estymacji parametrów równania (1) w okresie 1 kwartału 1999 roku - 2 kwartału 2008 roku

\begin{tabular}{|c|c|c|c|c|}
\hline Zmienna & Przed_kr(1) & Przed_kr(2) & Przed_kr(3) & Przed_kr(4) \\
\hline $\begin{array}{l}\text { Ryzyko } \\
\text { globalne }\end{array}$ & $.02137735 * * *$ & $.01969564 * * *$ & $.02055454 * * *$ & $.01892499 * *$ \\
\hline aktywa/kap. & $.02981123 * *$ & $.03156712 * * *$ & & \\
\hline$(\text { aktywa/kap. })^{2}$ & $-.0007219 * *$ & $-.00080549 * * *$ & & \\
\hline poż./dep. & & & -.17854397 & -.15603363 \\
\hline$(\text { poż./dep. })^{2}$ & & & -.1751825 & -.30084261 \\
\hline Płynność & $-.08442743^{*}$ & $-.0969171 * *$ & $-.08954727^{*}$ & $-.08126135^{*}$ \\
\hline $\mathrm{E}(\mathrm{BOB})$ & -.00038154 & .00064469 & -.00298553 & -.00277292 \\
\hline $\mathrm{E}(\mathrm{y})$ & .13907277 & 1.3158745 & .27950069 & 1.1876483 \\
\hline $\mathrm{E}$ (dług) & -.00056306 & -.00181321 & -.00119499 & -.00201913 \\
\hline $\mathrm{E}(\mathrm{dług})^{2}$ & .00001547 & $.00003769^{*}$ & .00003313 & $.00004158 *$ \\
\hline $\mathrm{E}$ (saldo gg) & $-.02692055^{* * *} *$ & $-.03401985 * * *$ & $-.02778807 * * *$ & $-.02868449 * * *$ \\
\hline $\mathrm{E}($ ulc) & .25506868 & $.21926904^{*}$ & .2452774 & .19269767 \\
\hline E(stopa oszcz.) & -.00390691 & $-.00585816^{* *}$ & .00471987 & $-.00617903 * *$ \\
\hline E(stopa bezr.) & .00820538 & .00338373 & .0079502 & .00350104 \\
\hline _cons & .25270578 & .30343424 & $.56795988 * *$ & $.51200367 * *$ \\
\hline $\mathrm{N}$ & 323 & 332 & 323 & 332 \\
\hline $\mathrm{r} 2$ & .45052318 & .45945337 & .44011501 & .4042158 \\
\hline
\end{tabular}

*,***** oznaczają istotność na poziomie (odpowiednio) 10\%, 5\% i $1 \%$.

Źródło: opracowanie własne.

Pierwszym wnioskiem dotyczącym wyników estymacji modelu na próbie obejmującej okres przed kryzysem finansowym jest w zasadzie brak możliwości wskazania najbardziej zbliżonego do rzeczywistości schematu oczekiwań. Niemniej jednak we wszystkich modelach na poziomie przynajmniej $10 \%$ istotne okazały się: wskaźnik globalnego ryzyka, płynność rynków obligacji, a także oczekiwane saldo sektora rządowego i samorządowego. Ponownie istotny (na poziomie 5 i 10\%) jest też stosunek aktywów do kapitału własnego i rezerw. Co jednak ciekawe, premię od rynków finansowych przed kryzysem dostawały kraje o bardzo wysokich wskaźnikach dźwigni. W modelach (2) i (4) istotne są także parametry przy kwadratach relacji długu do PKB, a także przy stopach oszczędności (tabela 2).

W tabeli 3 zamieszczono wyniki estymacji równania (1) przeprowadzonych na próbie obejmującej okres kryzysu. Wyniki te potwierdzają głęboką zmianę sposobu wyceny obligacji rządowych na rynkach finansowych. Po pierwsze, parametr przy wskaźniku globalnego ryzyka przyjmuje wartości 6-11-krotnie wyższe niż przed kryzysem. Po drugie, znaczenie straciła płynność rynków obligacji, mierzona wartością długu na rynku wtórnym. Po trzecie, wzrosły także wartości parametrów przy relacji długu publicznego do PKB, a także potwierdzona została nieliniowość związku między 
długiem a relatywnymi rentownościami obligacji. Po czwarte, rynki finansowe w większym stopniu zdają się analizować sytuację w sferze realnej: wyższa premia za ryzyko przypisywana jest krajom o niższej oczekiwanej stopie wzrostu PKB. Warto też zwrócić uwagę na brak statystycznej istotności salda budżetowego. Może to oznaczać, że ścierają się tu dwa mechanizmy wyceny obligacji, z jednej strony podwyższające premię za ryzyko $\mathrm{w}$ związku $\mathrm{z}$ akumulacją zadłużenia publicznego, a $\mathrm{z}$ drugiej - $\mathrm{w}$ wyniku obniżania krótkookresowych perspektyw wzrostu gospodarczego poprzez tradycyjne, keynesowskie efekty konsolidacji fiskalnej. Co więcej, wyłączenie z panelu Irlandii (wyniki nieraportowane w tabelach) skutkuje uzyskaniem dodatniego znaku i statystycznie istotnego parametru przy saldzie budżetowym.

Tabela 3. Wyniki estymacji parametrów równania (1) w okresie 3 kwartału 2008 roku -4 kwartału 2011 roku

\begin{tabular}{|c|c|c|c|c|}
\hline Zmienna & Kryzys(1) & Kryzys(2) & Kryzys(3) & Kryzys(4) \\
\hline $\begin{array}{l}\text { Ryzyko } \\
\text { globalne }\end{array}$ & $.15558867 * *$ & $.22841123 * * *$ & .12622852 & $.20390137 * *$ \\
\hline aktywa/kap. & $-.31992007 * *$ & $-.2783816^{* *}$ & & \\
\hline$(\text { aktywa/kap.) })^{2}$ & $.00616501^{*}$ & .00436011 & & \\
\hline poż./dep. & & & $-5.3454633 * * *$ & $-5.2704198 * * *$ \\
\hline$(\text { poż./dep. })^{2}$ & & & $10.714111^{* * *}$ & $10.256969 * * *$ \\
\hline Płynność & .03023075 & .91491314 & 1.0472781 & $2.4918328^{*}$ \\
\hline $\mathrm{E}(\mathrm{BOB})$ & $.10907987 * *$ & .03100711 & $.10626248^{* *}$ & .01826223 \\
\hline $\mathrm{E}(\mathrm{y})$ & $-11.98996 * * *$ & $-14.07596^{* * * *}$ & $-12.099836 * * *$ & $-16.336817 * * *$ \\
\hline $\mathrm{E}$ (dług) & $.08392117 * * *$ & $.08084834 * * *$ & $.09135014 * * *$ & $.08904063 * * *$ \\
\hline $\mathrm{E}(\mathrm{d} \text { ług })^{2}$ & $.00119799 * * *$ & $.00110858 * * *$ & $.0018239 * * *$ & $.0018591 * * *$ \\
\hline $\mathrm{E}$ (saldo gg) & -.01313084 & .00235739 & .00692383 & .0208543 \\
\hline $\mathrm{E}(\mathrm{ulc})$ & 1.9530101 & .82008269 & $3.2396394 *$ & 1.0137365 \\
\hline E(stopa oszcz.) & .02002712 & $.05035661 *$ & .00646841 & .03187674 \\
\hline E(stopa bezr.) & -.0110104 & .00400645 & .08418409 & .06755201 \\
\hline _cons & 2.9506758 & -2.9854984 & -5.4237521 & $-14.46922^{*}$ \\
\hline $\mathrm{N}$ & 74 & 67 & 74 & 67 \\
\hline $\mathrm{r} 2$ & .96796638 & .96769153 & .96746278 & .96147634 \\
\hline
\end{tabular}

*,**,*** oznaczają istotność na poziomie (odpowiednio) $10 \%, 5 \%$ i $1 \%$.

Źródło: opracowanie własne.

Reorientacja rynków finansowych w kierunku większej wagi przykładanej do popytowych uwarunkowań koniunktury gospodarczej jest też widoczna na przykładzie roli stopy oszczędności. O ile przed kryzysem znak przy tej zmiennej był ujemny (i w dwóch przypadkach statystycznie istotny), to w drugiej podpróbie znak jest już dodatni (i w jednym przypadku istotny). Pewnym zaskoczeniem może być uzyskany znak przy oczekiwanym saldzie obrotów bieżących, choć w okresie kryzysu eliminacja stanów 
nierównowagi zewnętrznej w krajach o wyjściowo wysokim deficycie dokonywała się poprzez spadek importu, generowany słabnącym popytem.

Wyniki wskazują też na nieliniowy wpływ zmiennych z sektora bankowego. Odwrotnie niż przed kryzysem wyższą premią za ryzyko obarczone są kraje, w których sektor bankowy działał przy wysokich wskaźnikach dźwigni finansowej lub niewielką część pożyczek zabezpieczał depozytami.

Uzupełnieniem analizy uzyskanych wyników estymacji może być ocena wkładu poszczególnych zmiennych w wyjaśniania zmienności relatywnych rentowności obligacji państw strefy euro. Ćwiczenie to zostanie przeprowadzone na podstawie metody zaproponowanej przez Bebera i wsp. ${ }^{45}$. Relatywny wkład zmiennej $X_{j}$ do zmienności relatywnej stopy oprocentowania obligacji w kraju i obliczany jest ze wzoru:

$$
\breve{X}_{j, i}=\frac{\left|\hat{\beta}_{j}\right| \cdot\left|\bar{X}_{j}\right|_{i}}{\sum_{j=1}^{n}\left|\hat{\beta}_{j}\right| \cdot\left|\bar{X}_{j}\right|_{i}}
$$

$\left|\bar{X}_{j}\right|_{i}$ jest modułem średniej wartości tej zmiennej w kraju i, w całej podpróbie. W tabelach 4 i 5 przedstawiono wyniki obliczeń uzyskanych na podstawie modeli oszacowanych na (odpowiednio) pierwszej i drugiej podpróbie, na podstawie wariantów tych oszacowań, które uzyskały najwyższe współczynniki determinacji. Do obliczeń wykorzystano tylko zmienne istotne statystycznie na poziomie istotności 0,1 , stąd wyniki należy traktować jako ich maksymalne relatywne wkłady.

Przed kryzysem największą część zmienności relatywnego oprocentowania obligacji w strefie euro pełniła zmienna $\mathrm{z}$ sektora bankowego (w tym wypadku relacja aktywów do kapitału własnego i rezerw) oraz wskaźnik płynności rynków obligacji. Zmienne fiskalne były ważne dla zmienności rentowności obligacji fińskich (podobnie stopa oszczędności), natomiast ewolucja jednostkowych kosztów pracy - dla obligacji greckich. Wahania globalnej awersji do ryzyka odpowiadały za 3,7-7,1\% zmienności stóp procentowych.

W okresie kryzysu zapoczątkowanego przez upadek Lehman Brothers zdecydowanie zwiększyła się rola długu publicznego w wielu krajach, w tym w wysoce zadłużonych gospodarkach Grecji i Włoch, ale także w Finlandii, wyróżniającej się wciąż niską wartością tej zmiennej (por. tabela 5). We wszystkich krajach strefy euro z wyjątkiem Grecji nastąpił też dalszy wzrost znaczenia zmiennej ilustrującej sytuację w sektorze bankowym (ponownie relacja aktywów do kapitału własnego i rezerw).

${ }^{45}$ A. Beber, M.W. Brandt, K.A. Kavajecz, op. cit.; por. też M.G. Attinasi, C. Checherita, C. Nickel, op. cit. 
Tabela 4. Maksymalne relatywne kontrybucje poszczególnych zmiennych do zmienności relatywnych rentowności obligacji w okresie 1 kwartału 1999 roku - 2 kwartału 2008 roku

\begin{tabular}{|c|c|c|c|c|c|c|c|}
\hline & $\begin{array}{l}\text { Sektor } \\
\text { bankowy }\end{array}$ & Płynność & $\begin{array}{l}\text { Dług } \\
\text { publiczny }\end{array}$ & $\begin{array}{l}\text { Saldo } \\
\text { budżetowe }\end{array}$ & Ulc & $\begin{array}{l}\text { Stopa } \\
\text { oszczędności }\end{array}$ & Ryzyko \\
\hline AUT & $54,5 \%$ & $36,3 \%$ & $0,0 \%$ & $2,4 \%$ & $0,5 \%$ & $0,8 \%$ & $5,5 \%$ \\
\hline BEL & $60,8 \%$ & $27,8 \%$ & $2,5 \%$ & $3,5 \%$ & $1,0 \%$ & $0,6 \%$ & $3,7 \%$ \\
\hline ESP & $40,1 \%$ & $44,4 \%$ & $0,9 \%$ & $5,9 \%$ & $3,2 \%$ & $0,0 \%$ & $5,5 \%$ \\
\hline FIN & $42,7 \%$ & $31,3 \%$ & $1,3 \%$ & $13,6 \%$ & $1,3 \%$ & $4,0 \%$ & $5,8 \%$ \\
\hline FRA & $46,1 \%$ & $46,3 \%$ & $0,0 \%$ & $0,5 \%$ & $1,3 \%$ & $0,9 \%$ & $4,9 \%$ \\
\hline GRC & $41,7 \%$ & $39,0 \%$ & $4,6 \%$ & $1,0 \%$ & $6,0 \%$ & $1,4 \%$ & $6,4 \%$ \\
\hline IRL & $56,0 \%$ & $27,4 \%$ & $2,5 \%$ & $7,1 \%$ & $2,3 \%$ & $0,0 \%$ & $4,8 \%$ \\
\hline ITA & $39,1 \%$ & $47,7 \%$ & $4,8 \%$ & $0,5 \%$ & $2,4 \%$ & $0,4 \%$ & $5,0 \%$ \\
\hline NLD & $57,8 \%$ & $32,5 \%$ & $0,3 \%$ & $2,9 \%$ & $1,8 \%$ & $0,7 \%$ & $4,1 \%$ \\
\hline PRT & $44,9 \%$ & $40,7 \%$ & $0,1 \%$ & $2,1 \%$ & $5,0 \%$ & $0,3 \%$ & $7,1 \%$ \\
\hline
\end{tabular}

Źródło: opracowanie własne.

Oczekiwany wzrost PKB, mimo zyskania statystycznej istotności w czasie kryzysu, odpowiada jednak za niewielką część zmienności relatywnych rentowności obligacji.

Tabela 5. Maksymalne relatywne wkłady poszczególnych zmiennych do zmienności relatywnych rentowności obligacji w okresie 3 kwartału 2008 roku - 4 kwartału 2011 roku

\begin{tabular}{|lrrrrr|}
\hline & \multicolumn{1}{c}{$\begin{array}{l}\text { Sektor } \\
\text { bankowy }\end{array}$} & BOB & \multicolumn{2}{c|}{ PKB } & \multicolumn{2}{l}{$\begin{array}{l}\text { Dlug } \\
\text { publiczny }\end{array}$} & Ryzyko \\
AUT & $71,5 \%$ & $3,9 \%$ & $0,3 \%$ & $9,4 \%$ & $14,9 \%$ \\
BEL & $72,1 \%$ & $4,2 \%$ & $0,1 \%$ & $16,2 \%$ & $7,4 \%$ \\
ESP & $53,7 \%$ & $12,3 \%$ & $1,2 \%$ & $22,4 \%$ & $10,5 \%$ \\
FIN & $61,3 \%$ & $2,7 \%$ & $0,1 \%$ & $28,4 \%$ & $7,5 \%$ \\
FRA & $77,9 \%$ & $8,1 \%$ & $0,2 \%$ & $3,2 \%$ & $10,4 \%$ \\
GRC & $34,6 \%$ & $11,7 \%$ & $1,8 \%$ & $45,4 \%$ & $6,6 \%$ \\
IRL & $74,3 \%$ & $6,4 \%$ & $3,5 \%$ & $6,4 \%$ & $9,5 \%$ \\
ITA & $39,2 \%$ & $7,7 \%$ & $1,2 \%$ & $43,7 \%$ & $8,3 \%$ \\
NLD & $80,2 \%$ & $1,1 \%$ & $0,3 \%$ & $10,8 \%$ & $7,6 \%$ \\
PRT & $60,3 \%$ & $18,9 \%$ & $1,8 \%$ & $7,5 \%$ & $11,6 \%$ \\
\hline
\end{tabular}

Źródło: opracowanie własne.

Co ciekawe, zdecydowanie mniejsza od oczekiwanej jest rola wskaźnika globalnego ryzyka. Wprawdzie wzrosła ona we wszystkich krajach, ale kształtuje się w granicach 6,6-14,9\%, czyli zdecydowanie poniżej wartości uzyskanych w pracy 
Attinasi i wsp. ${ }^{46}$, gdzie jednak nie uwzględniono żadnych zmiennych $\mathrm{z}$ sektora bankowego.

\section{PODSUMOWANIE}

Wyniki przeprowadzonych analiz potwierdzają wystąpienie silnej zmiany sposobu wyceny obligacji rządowych w strefie euro pod wpływem kryzysu finansowego. Wśród zmiennych fiskalnych i makroekonomicznych branych pod uwage we wcześniejszym okresie istotne przełożenie na rentowność obligacji miały: oczekiwane saldo sektora rządowego i samorządowego oraz być może oczekiwana stopa oszczędności (im wyższa, tym niższe rentowności), a także dynamika jednostkowych kosztów pracy (im wyższa, tym wyższe rentowności). Wyższą premią za ryzyko obarczane były też prawdopodobnie gospodarki o zdecydowanie wyższej relacji długu do PKB w porównaniu z Niemcami, choć na podstawie wyników obliczeń nie można tego jednoznacznie przesądzić. Po upadku Lehman Brothers oprocentowanie obligacji w większym stopniu niż wcześniej jest kształtowane pod wpływem wahań globalnego ryzyka, chociaż były one istotne także wcześniej. Jednocześnie rynki finansowe zdecydowanie większą wagę przywiązują do długu publicznego oraz krótkookresowych perspektyw wzrostu gospodarczego.

Reorientacja uwagi w kierunku popytowych uwarunkowań wzrostu jest widoczna także $\mathrm{w}$ związku $\mathrm{z}$ dodatnim oszacowaniem parametru przy saldzie na rachunku obrotów bieżących i stopie oszczędności, chociaż w wypadku tej ostatniej zmiennej oszacowany parametr jest na granicy (lub poza nia) istotności statystycznej na poziomie istotności $10 \%$. Dodatkowym sygnałem, który może potwierdzać omawiane zjawisko, jest nieistotność oczekiwanego salda sektora rządowego i samorządowego, co może oznaczać, że rynki finansowe z jednej strony premiują redukcję długu publicznego, a z drugiej są sceptyczne wobec konsolidacji fiskalnych, które mogą szkodzić wzrostowi PKB.

Z analizy kontrybucji poszczególnych zmiennych do wyjaśniania zmienności relatywnych stóp oprocentowania obligacji wynika, że relacja aktywów do kapitału własnego i rezerw była najsilniejszym czynnikiem zarówno przed kryzysem, jak i w trakcie jego trwania. Silnym czynnikiem przed kryzysem był też wskaźnik płynności krajowych rynków obligacji, natomiast później w większości krajów istotna stała się relacja długu do PKB. Znaczenie wahań globalnego ryzyka rzeczywiście wzrosło (jak dowodzi większość artykułów na ten temat), ale ogólnie pozostaje na dość niskim poziomie. Można zatem podsumować, że obserwowane ostatnio nasilenie badań w kierunku analiz związków między ryzykiem kredytowym krajów a sektorem bankowym jest kluczowe z punktu widzenia zrozumienia sposobu wyceny obligacji na rynkach finansowych.

\section{LITERATURA}

[1] Aßmann C., Boysen-Hogrefe J., Determinants of government bond spreads in the Euro Area - in good Times as in bad, ,Kiel Working Paper” 2009/1548.

[2] Acharya V., Drechsler L., Schnabl P., A Pyrrhic Victory? - Bank Bailouts and Sovereign Credit Risk, „NBER Working Papers” 17136 (2011).

\footnotetext{
${ }^{46}$ M.G. Attinasi, C. Checherita, C. Nickel, op. cit.
} 
[3] Alesina A., De Broeck M., Prati A., Tabellini G., Default Risk on Government Debt in OECD Countries, "Economic Policy" 1992/15, s. 427-451.

[4] Arellano M., Bond S., Some Tests of Specification for Panel Data: Monte Carlo Evidence and an Application to Employment Equations, „Review of Economic Studies", 1991/58(2), s. 277-97.

[5] Arghyrou M., Kontonikas A., The EMU sovereign-debt crisis: Fundamentals, expectations and contagion, "Cardiff Economics Working Papers" 2010/9.

[6] Attinasi M.G., Checherita C., Nickel C., What Explains the Surge in Euro Area Sovereign Spreads during the Financial Crisis of 2007-09?, „ECB Working Paper" 2009/1131.

[7] Barbosa L., Costa S., Determinants of sovereign bond yield spreads in the euro area in the context of the economic and financial crisis, Economic Bulletin and Financial Stability Report Articles, Banco de Portugal, Economics and Research Department 2010.

[8] Barrios S., Iversen P., Lewandowska M., Setzer R., Determinants of IntraEuro Area Government Bond Spreads during the Financial Crisis, „EC Economic Papers" 2009/388.

[9] Beber A., Brandt M.W., Kavajecz K. A., Flight-to-Quality or Flight-toLiquidity? Evidence from the Euro-Area Bond Market, „Review of Financial Studies, Oxford University Press for Society for Financial Studies" 22/3 (2009), s. 925-957.

[10] Beck N., Katz J. N., What To Do (and Not To Do) with Time-Series CrossSection Data, „American Political Science Review” 1995/89, s. 634-47

[11] Bernoth K., von Hagen, J., Schuknecht L., Sovereign risk premia in the European government bond market, "ZEI Working Papers" B 26-2003, ZEI Center for European Integration Studies, University of Bonn (2003).

[12] Blanchard O., Driving the Global Economy with the brakes on, blogpost, Styczeń 2012.

[13] Borys P., Ciżkowicz P., Rzońca A., Panel data evidence on non-Keynesian effects of fiscal policy in the EU New Member States, „MPRA Paper” 2011/32696, University Library of Munich, Germany.

[14] Caggiano G. Greco L., Sovereign Risk in the Euro Area: Is it Mostly Fiscal or Financial, mimeo, 2011.

[15] Codogno L., Favero C. Missale A., Yield spreads on EMU government bonds, „Economic Policy” 2003/18, s. 503-532.

[16] Corsetti G., Has Austerity Gone Too Far?, VOXEU.org, 2.04.2012 r

[17] De Grauwe, P., Ji Y., Mispricing of Sovereign Risk and Multiple Equilibria in the Eurozone, „CEPS Working Document No 361” (2012).

[18] De Santis R., The Euro area sovereign debt crisis: safe haven, credit rating agencies and the spread of the fever from Greece, Ireland and Portugal, Working Paper Series 1419, European Central Bank (2012).

[19] Favero C., Pagano M., von Thadden E., Valuation, Liquidity and Risk in Government Bond Markets, „IGIER Working Paper” 2005/281.

[20] Gerlach S., Schulz A., Wolff G., Banking and Sovereign Risk in the Euro Area, CEPR Discussion Paper No. DP7833, 2010.

[21]Geyer A., Kossmeier S., Pichler S., Measuring systematic risk in EMU government yield spreads „Review of Finance” 2004/8(2), s.171-197. 
[22] Gómez-Puig M., Monetary integration and the cost of borrowing, ,Journal of International Money and Finance" 27/3 (2008), s. 455-479.

[23] Haugh D., Ollivaud P., Turner D., What Drives Sovereign Risk Premiums?: An Analysis of Recent Evidence from the Euro Area, „OECD Economics Department Working Papers" 2009/718.

[24] Manganelli S., Wolswijk G., What Drives Spreads in the Euro Area Government Bond Market?, „Economic Policy” 2009/58, s. 191-240.

[25] Międzynarodowy Fundusz Walutowy, Navigating the Fiscal Challenges Ahead, Fiscal Monitor (Washington), Maj 2010.

[26] Moody A., From Bear Stearns to Anglo Irish: How Eurozone Sovereign Spreads Related to Financial Sector Vulnerability, „IMF Working Paper” 9/108 (2009).

[27] Pagano M., von Thadden E., The European Bond Markets Under EMU, „CEPR Discussion Paper” 2004/4779.

[28] Portes J., Is austerity self-defeating? Of course it is, VOXEU.org, 10.04.2012 r.

[29] Sgherri S. Zoli E., Euro Area Sovereign Risk During the Crisis, „IMF Working Paper" 9/222 (2009).

[30] Schuknecht L., von Hagen J., Wolswijk G., Government Bond Risk Premiums in the EU Revisited. The Impact of the Financial Crisis, „ECB Working Paper” $2010 / 1152$.

\section{FINANCIAL CRISIS AND DETERMINANTS OF GOVERNMENT BOND YIELDS IN THE EURO AREA}

The paper attempts to examine how financial markets changed its attitude towards assessing government bonds in the Euro Area countries during the financial crisis. Compared to other papers, more attention is devoted to the expectation schemes observed in financial markets. Four alternative schemes are constructed and compared to examine how far-sighted markets have been.

The study is conducted on quarterly data, encompassing the period 1999-2011. The emphasis is put on the role of fiscal and macroeconomic variables and the situation of banking sectors. The results confirm a strong shift in the behavior of financial markets. The crisis contributed to an increased role of public debt, the demand-side factors driving economic growth and (obviously) international risk factor. At the same time, the importance of bond market liquidity, one of the most important factor driving bond yields before the crisis, declined markedly. The contribution analysis shows that both before the crisis and (even more so) after the collapse of the Lehman Brothers, risk premium has been strongly linked to the situation in the banking sector, especially the leverage ratios. This suggests that the sovereign-banking nexus is an important source of the observed premium risk fluctuations.

Keywords: fiscal policy, financial crisis, Eurozone

DOI:10.7862/rz.2014.hss.16

Przesłano do redakcji: grudzień 2013

Przyjęto do druku: wrzesień 2014 